\title{
PaRASITES ORdinaIRES DES PORCS EN FRANCE DIAGNOSTIC ISOLEMENT DES SOUCHES POUR INFESTATIONS EXPÉRIMENTALES
}

\author{
J. P. RAYNAUD
}

Station de Recherches et Développement vétérinaire et Nutrition animale, PFIZER, 37 - Amboise

\section{RÉSUMÉ}

Un survol sur les parasites ordinaires des porcs en France est présenté en distinguant les élevages contrôlés sur le plan technique, soumis en continu à des traitements de routine, et des élevages à traitements systématiques irréguliers ou absents.

Un cas particulier de la charge parasitaire des porcelets au sevrage lorsque les mères sont parasités par Hyostrongylus et Oesophagostomum spp. est présenté.

Les techniques de diagnostic au laboratoire sont envisagées : Coproscopie, coproculture, autopsie. Pour l'étude expérimentale des maladies et des anthelminthiques nous avons isolé et nous entretenons en continu sur porcelets sains: Strongyloides ransomi, Hyostrongylus rubidus Oesophagostomum dentatum et Oesophagostonum granatensis.

Un cas particulier de l'efficacité du Morantel (Pfizer) sur les stades immatures d'Oesophagostomum est présenté.

\section{SUMMARY}

ORDINARY PARASITES OF SWINE IN FRANCE; DIAGNOSIS ; ISOLATION FOR EXPERIMENTAL INFESTATIONS

As a whole the ordinary parasites of swine in France are presented distinguishing :

- herds controlled on a technical level, with systematic treatments in routine.

- herds where these systematic treatments are irregularly done or not done at all.

An example is given on the parasitic intake of suckling piglets until weaning when the sows are infested with Hyostrongylus and Oesophagostomum spp.

The technics of diagnosis in laboratory facilities are considered : coproscopic examination, coprocultures and post mortem examination. For experimental infestations and drugs efficacy studies we have isolated and we kept with continuous passages on healthy piglets : Strongyloides ransomi, Hyostrongylus rubidus, Oesophagostomum dentatum, Oesophagostomum granatensis.

A particular case, on the efficacy of Morantel (Pfizer) on Oesophagostomum immature stages is presented. 